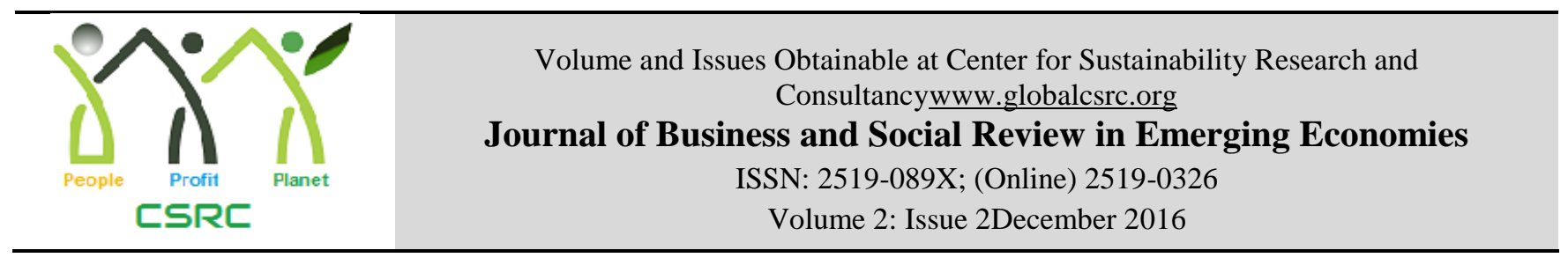

\title{
Resistance to Change of Academics towards Accreditation
}

\author{
${ }^{1}$ Kadzrina Abdul Kadir, ${ }^{2}$ Darwina Ahmad Arshad, ${ }^{3}$ Johanim Johari \\ ${ }^{123}$ School of Business Management, College of Business, Universiti Utara Malaysia \\ kadzrina@uum.edu.my
}

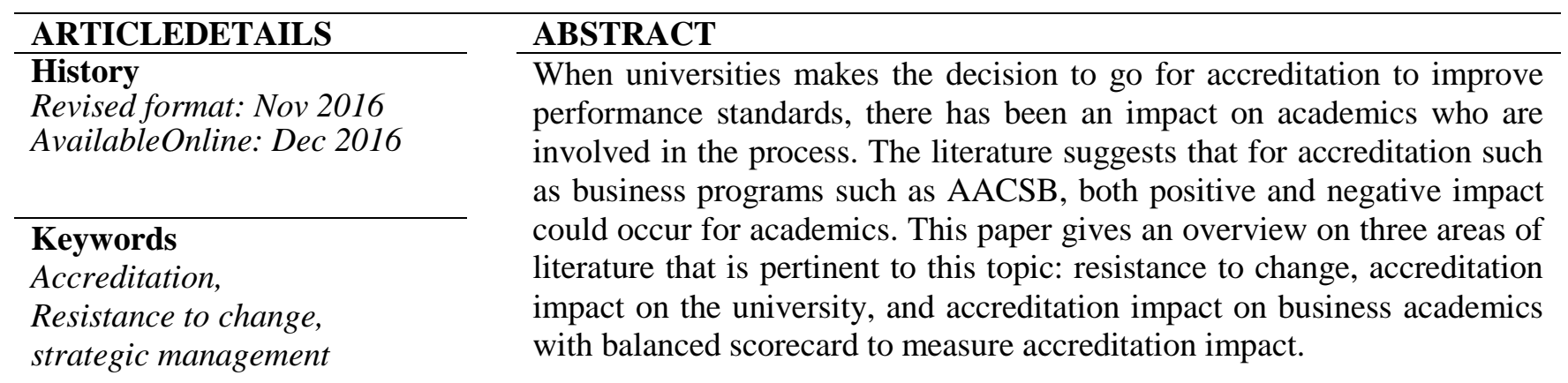

JEL Classification:

M10,M19

(C) 2016 The authors, under a Creative Commons Attribution-

NonCommercial 4.0

\section{Background}

For some countries, like Malaysia, education play an important role as education is expected to enable the increase in knowledge which would lead to improvements in capability and hopefully would facilitate change. Education in Malaysia receives significant investment from the Government, with annual total expenditure on education equivalent to $7.7 \%$ of annual Government expenditure, with higher education itself receiving 5.5\% (Malaysian Education Blueprint [Higher Education] 2015-2025, Executive Summary p1-4). This significant investment in education and talent management of its future workforce suggest that the Government have high expectations on the actors involved - particularly the higher learning education (HLIs). Thus, in return for continued government funding, public HLIs must ensure achievement of performance outcomes and incentives for exceeding those outcomes (Malaysia Education Blueprint [Higher Education] 2015-2025, Executive Summary p1-20). In addition, the *Corresponding Author's Email Address: kadzrina@uum.edu.my 
Malaysian government targets Malaysia as a 'regional hub' for education in the ASEAN/Asian region, thus having competitive, globally accredited universities would enable that target to be achieved.

\section{2. $\quad$ Reduced Budget in 2016}

In 2016, the education sector, particularly public universities were faced with reduced level of government spending due to the impact of global uncertainty as well as the reduction in the price of oil and commodity prices on the nation. The Malaysian Government in its 2016 budget implemented a $15 \%$ cut in higher education spending for 2016 and 19 out of the 20 public universities saw their allocations reduced with highest at $27.3 \%$ for Universiti Malaya (Sharma, 2015). In total, the Higher Education sector sees a decrease of RM1.4 billion (USD\$325 million) compared with the previous year, a decrease of $15 \%$ from RM15.79 billion in 2015 compared to RM13.3 billion in 2016 (Sharma, 2015).

Constraints due to budget cuts increase the demands on universities and its staff in implementing its activities, much less in activities to improve its performance in order to attain accreditation, particularly regional or global accreditations. Other countries which have faced such circumstances earlier report the impact on the universities. In Australia for example, the significant cuts in funding have lead to higher student/staff ratios, over-enrolments, staff shortages, larger classes and poorer quality students (see PopVasileva, Baird and Blair, 2014). The authors noted that such changes could have greater impact on certain faculties, such as accounting, expected as 'cash cows' in certain universities. The authors observed that the circumstances were also occurring when expectations were universities were expected to be more fiscally responsible. Such conditions faced in Australia is slowly being felt in Malaysia, thus the circumstances stated by the authors on staff shortages as well as issues of infrastructure and student quality could be felt in the near future for Malaysian universities.

In this circumstances, implementing or earning a global accreditation is not easy, and the literature suggest that any organisations, such as universities, which are in the process of implementing change will face resistance from its staff (see Julian \&Ofori-Dankwa, 2006). Research on the impact of accreditation on academic staff has been few (van Kemenade and Hardjono, 2009). The authors argued that this was surprising given that research has shown that success in quality improvement in organisations were dependent on the ability to change of staff (see van Delden, 1992). The authors noted from research presented in conferences and journalistic articles, that there seems to be resistance from lecturers towards accreditation process though organisations could benefit from the accreditation itself. In their study on Netherlands universities, the author found that factors leading to resistance among staff towards accreditation include high workload, negative emotions (stress) as well as lack of knowledge and lack of acceptance (van Kemenade and Hardjono, 2009).

\section{Aim of the Paper}

This paper focuses specifically on the resistance to change towards achieving accreditation using the focus on the global accreditation from Association to Advance Collegiate Schools of Business (AACSB). AACSB is a global accreditation for business management courses for both undergraduate and postgraduate courses. AACSB itself acknowledges that its accreditation is one of the most difficult that universities face, as AACSB has a strict criteria that must be met by universities. Though the accreditation could bring positive outcomes to the university itself, what are the impact that it might have on the academic staff, especially with regard to resistance of change from staff? Specifically, what are the impact, both positive and negative that might have on the academic staff? The aim of this research paper is to present an overview on three areas of literature that is pertinent to this topic: resistance to change, accreditation impact on the university as well as accreditation impact on business academics. 


\section{AACSB accreditation}

Among the well-known global accreditation of business management programs are The Association of MBA (AMBA), The Association to Advance Collegiate Schools of Business (AACSB) and European Quality Improvement System (EQUIS) - global accreditation of business management programs at both undergraduate and postgraduate levels. This paper focuses on the impact of the accreditation process towards achieving the AACSB accreditation has on university academics. AASCB is an international accreditation of business schools programs, headquartered in the US. AACSB International is in charge of accreditation of universities outside the United States. AACSB provides "internationally recognised, specialised accreditation for business and accounting programs at the bachelor's, master's, and doctoral level. The AACSB accreditation standards challenge post-secondary educators to pursue excellence and continuous improvement throughout their business programs. AACSB accreditation is known, worldwide, as the longest standing, most recognised form of specialised/ professional accreditation an institution and its business programs can earn" (AACSB website). The AACSB has more than 90 years of history of recognising excellence in management education and is the largest and most recognisedspecialised accreditation worldwide. AACSB informs through its website that the accreditation is very stringent with $86 \%$ of universities (schools) noting that the standards are the most stringent as compared to other accreditations (AACSB website). Furthermore, the current standards in business education from AACSB's point of view is that schools should be currently focusing on Engagement, Innovation and Impact in managing their programs. Currently, out of 353 AACSB members in Asia (universities who are starting or in the process of being accredited), only 84 universities or schools are accredited with AACSB (as at February 2016).

Thus, the high standards of AACSB has an impact on the university academics in terms of preparing, addressing and implementing programs to enhance the standards of teaching, research, publication as well as general management of business programs in schools, with the focus on improving the standards for the students. One consequence of the AACSB accreditation is the qualification of lecturers who teach business courses in the university (or 'schools') as they need to have a PhD in order to teach, thus increasing the pressure to complete a PhD and publish (Hermanson, 2008), leading to situations where both academics and research students are competing to publish in the same journals (Mathews, 2007, Pop-Vasileva et al, 2014). One consequence of this circumstances are where some early career academics are leaving their institutions and thus universities are facing issues of retaining high quality staff (Pop-Vasileva et al, 2014). The next section looks at both positive and negative impacts that accreditation has on academics.

Therefore the higher standards expected as a result of preparing to acquire accreditation as well as maintaining accreditation could result in increasing academics' as well as administrators resistance to change. For this paper, viewpoint of academics is the focus.

\section{Resistance to Change}

To achieve accreditation is not easy for universities. For many universities, they start as teaching institutions, and slowly, change towards focusing on research and publication as well as internationalising their outlook. Therefore, it is not surprising that entrenched staff, particularly academic staff, might be resistant to change, especially if the staff had been senior academics or have had many years of focusing on teaching and now are asked to change towards other areas. Thus top management of universities need to deal with the resistance to change of their staff, and find ways to strategically manage in order that change could occur in a positive manner, without negative consequences to the university in the future. The situations facing universities are not unusual. 
Corporations and other organisations too are facing change in their own way, with more uncertain economic outlook, for example the 'Brexit' impact on UK and EU in 2016.

Strategic Management

Thus, how do organisations manage resistance to change? In strategic management, several strategies are suggested. David and David (2015) suggest that in order to face resistance to change, these types of strategy might be implemented: Force change strategy - involves giving orders and enforcing those orders; educative change strategy - one that presents information to convince people of the need for change, as well as self-interest change strategy - one that attempts to convince individuals that the change is to their personal advantage. Therefore, for top management of universities, one or a combination of all three types of strategies might be suggested. A research study on the type of strategy, if any, that is implemented when a university is implementing processes towards achieving a global accreditation could be done.

Resistance to change is perhaps understandable. The human being is against change and prefers the comfort zone of what is familiar. However, research has shown that change is possible and performance could improve. For example, based on a study of two Canadian health organisations, these organisations showed that changes were made where there were improvements at the systems and management practices as well as external communications (see Lanteigne\& Bouchard, 2016). The study suggest that among the stages of the accreditation process, the 'self-assessment' and 'make improvements and follow up on recommendations' were the most useful as it contributed the most to change. As facilitators, the interdisciplinary accreditation teams were preferred as change agents (Lanteigne\& Bouchard 2016). However, the authors cautioned that the organisations still had a long way to go. Their improvement had yet to achieve the minimum level of requirement to achieve accreditation without restrictions, and the organisations had to find a way to formalize the changes made into the organisations' systems.

From the context of an academic environment like universities, the study by Ingram, House, Chenoweth, Dee, Ahmed, Williams, Downing and Richards (2014), recognized that for academics to be 'agents of change' there need to be acquisitions of skills, understanding institutional contexts, achieving specific structure of support as well as attaining four types of resources - namely targeted reading, for example books such as Kotter and Whitehead's "Buy-in", developing group partners, making time for focused work as well as an action plan (Ingram et al, 2014).

Accreditation process could also indirectly lead to organizational change, though accreditation itself on its own is not enough, and need to be supported with powerful interests in order to generate direct change (Cooper, Parkes \&Blewitt, 2014). White, Paslawski and Kearney (2013) noted that in the education sector, reasons usually cited for failure to change include: lack of understanding and support from faculty, lack of skills needed for change as well as lack of coordination and assessment of change (Rollins et al, 1999, Genn, 2001, Sefton 2004). In addition, for medical schools, White et al (2013) noted the literature suggest that conservative culture, territorial conflicts and defending current practices as other factors (Bernier et al. 2000; Lane 2007) that has impact on resistance to change. In their study, White et al (2013) discovered that one way to bring about rapid change is to acknowledge that resistance to change was going to be an issue but to go ahead and through innovative leadership, and with the right support for the 'agents of change', they were able to achieve success. The authors also noted that the (medical) faculty realized that education for the faculty now played a more important role than before Thus, the aspect of resistance to change of an organization towards change, such as that when acquiring accreditation or in some cases, to reaccredit after losing an accreditation, suggest that organisations need to consider carefully the process of accreditation and the impact that it has on an organization. The literature has suggested both positive and negative impacts of accreditation and the next section discuss this. 


\section{Positive Impact of Accreditation}

Overall, though, some researchers emphasise that accreditation such as AACSB have many benefits and suggest that lack of information from academics could be the source of uncertainty. Romero (2008) suggest that AACSB have positive impact on business school strategy, encourage creativity, and various value-added through accreditation-related reporting. In addition, he states that ACCSB has also flexible guidelines in areas of graduate admission, faculty qualification, and curriculum requirements.

In terms of learning, though AACSB could promote Organisational Learning and have a focus on quality, research productivity and innovative programming are not guaranteed. But the schools could at least ensure that they have participated with peer review exercise and in addition, the schools also need to ensure results are sustained (Elliot \& Goh (2013).

In terms of performance, accredited schools show greater improvement compared to unaccredited schools over a period of time, and with large magnitudes - nearly 5\% greater (between 1997-2007) passing for candidates with all parts taken, and 7\% difference for passing for candidates with some parts taken, as mentioned by Morgan (2011). The author discussed the case of a university with an engineering program.

\section{Negative Impact of Accreditation}

The negative impact of accreditation as noted in the literature include workload increase - which were towards peripheral task - preparation, formalisation of documents, meetings (Lichy\&Pon, 2015). In addition, the impact could also be on the industry practitioners - Lightbody (2010) noted that as Australian business schools pursue AACSB accreditation, this may have a number of negative consequences for universities. It may in fact exacerbate, rather than relieve, the current shortage of accounting faculty and result in a fall in teaching quality. The loss of ex-practitioners from the teaching faculty may also result in accounting programs that are perceived as less relevant and engaging by students (Lightbody, 2010). While another negative impact is with regard to student teaching: accreditation could change the focus of business education towards mission-linked approach, promotes growth but at the expanse of pedagogy (Lowrie\& Willmott, 2009).

There are also concerns in the literature that top management of business schools are seeking accreditation in order to achieve legitimacy benefits rather than performance benefits (Hodge, 2010). This notion is also supported by Lightbody (2010) who noted that many Australian business schools are seeking to become AACSB accredited in order to increase their marketability for students. In addition, some researchers also suggest that top management has reward and systems in place to train and reward accordingly: "Must be thoroughly trained in supervisory and management practices, including defining desired behavior, linking rewards to the behavior, managing performance, creatively designing broad reward systems and leveraging tenure and faculty governance systems" (Day and Peluchette, 2009).

\section{Stress and Jobs Less Rewarding}

Roberts, Johnson \& Groesbeck (2004, pg. 124) noted that salary increases do not accrue to faculty who must suffer through accreditation process with $22.2 \%$ of the respondents imply that there were salary adjustments, while on average it appears that faculty are suffering more stress and find their jobs less rewarding, still $22.4 \%$ disagree that their jobs are more stressful, and in fact a small number, 23.3.\%, agree that their work is more rewarding. Thus the authors suggest that "...any school contemplating seeking AACSB accreditation needs to evaluate the results in light of their idiosyncratic circumstances" (pg.124). This suggest that each university or schools might face unique experiences, and that though many academics might complain that they face more stress and higher workload, there might be a small number of academics who might disagree. Thus, if a research could uncover the reasons why or the strategies that worked for a particular group, this would contribute to literature. 
In summary, the literature has shown that in terms of resistance to change, the leadership and management of organisations need to ensure that they are ready to face several issues which concern the accreditation that schools/ universities face with academics. Some concerns such as the higher workload and stress due to the accreditation exercise as well as the preparation, while others are concerned with negative impact of the accreditation itself. However, some literature also pointed out the benefits of the accreditation exercise, including increase in performance. However, the strategy of top management in their strategy with academics need to be considered and academics should be trained, motivated and rewarded accordingly.

Therefore, for top management of universities, one or a combination of all three types of strategies might be suggested. A research study on the type of strategy, if any, that is implemented when a university is implementing processes towards achieving a global accreditation could be done.

To analyse the impact of the change on university, one way would be to utilise the Balanced Scorecard.

\section{Balanced Scorecard}

Strategic management focuses on how managers or organisations make decisions on determining the long-run performance of the organisation with regard to the firm's resources (Wheelen and Hunger, 2010). Thus, the drive towards improving the performance of the organisation (the university) through accreditation, qualification and attaining RU status has an impact on how the top management manages its resources (particularly, academic staff).

The Balanced Scorecard approach to strategy evaluation aims to balance long-term with short-term concerns, to balance financial with nonfinancial concerns, and to balance internal with external concerns (David \& David, 2015). Thus, questions that top management should be asking are as follows: How well is the firm continually improving and creating value along measures such as innovation, technological leadership, product quality, operational process, efficiencies, and so on? (David \& David, 2015).Wheelen and Hunger (2012) suggest that Balanced scorecard-combines financial measures that tell results of actions already taken with operational measures on customer satisfaction, internal processes and the corporation's innovation and improvement activities, and thus could be divided into these four areas: Financial, Customer, Internal business perspective, and Innovation and learning.

Thus, using the Balanced Scorecard, future research could examine four criteria to evaluate the performance of the university based on the impact of AACSB accreditation: 1) Internal Customers (Staff): Impact on academic staff, 2) Customer: Impact on students, 3) Financial: Impact on Financial and 4) Innovation and learning: Impact on activities such as research and publication.

In conclusion, this paper has discussed some pertinent issues with regard to resistance to change, particularly in the education sector, when universities have to face an aspect of change due to either acquiring an accreditation, such as AACSB, and the overall overview of the accreditation impact on academics, and with a view on analyzing the impact using the Balanced Scorecard.

\section{References}

AACSB International, Member institutions, viewed February 11, 2016, <http: www. aacsb.edu>

Bernier G,M., Adler, S., Kanter, S, and Meyer, W.J. (2000). On changing curricula: Lessons learned at two dissimilar medical schools. Acad Med 75(6):595-601.

Cooper, S., Parkes, C.,andBlewitt, J. (2014) "Can accreditation help a leopard change its spots?: Social accountability and stakeholder engagement in business schools", Accounting, Auditing \& Accountability Journal, 27 (2), pp.234 - 258. http://dx.doi.org/10.1108/AAAJ-07-2012-01062 
David, F \& David, F (2015). Strategic Management: Concepts and Cases. 15th edition, Pearson, New Jersey.

Day, N. E., \&Peluchette, J. (2009). Do we practice what we preach? An exploratory study about how business schools manage their human resources. Journal of Leadership \& Organizational Studies, 15(3), 275-286.

Elliott, C. J., \& Goh, S. C. (2013). Does accreditation promote organizational learning? A multiple case study of Canadian university business schools. Journal of Management Development, 32(7), 737-755.

Genn J,M. (2001). AMEE Medical Education Guide No. 23 (Part 1): Curriculum, environment, climate, quality and change in medical education- a unifying perspective. Med Teac 23(4):337-344.

Hodge, T. A. (2010). Acreditation of Business Schools: An explanatory multiple-case study of their motivations. Masters Thesis, University of Canterbury.

Hoque, K. E., Alam, G. M., Shamsudin, F., Akbar, S. Z. A., Moktharuddin, R. N., \& Fong, Y. S. (2010). The Impact of foreign lecturers' recruitment on higher education: An analysis from the Malaysian standpoint. African Journal of Business Management 4(18), 3937-3946.

Ingram, E.L. House, R.A., Chenoweth, S., Dee, K.C, Ahmed, J., Williams, J.M., Downing, C.G. and Richards, D.E. (2014) From Faculty to Change Agent: Lessons Learned in the Development and Implementation of a Change Workshop, Proceedings of the 121st ASEE Annual Conference and Exposition, Indianapolis, IN, June 18-20, 2014, Paper ID \#9682.

Julian, S. D., \&Ofori-Dankwa, J. C. (2006). Is Accreditation Good for the Strategic Decision Making of Traditional Business Schools? Academy of Management Learning \& Education, 5(2), 225-233.

Lane, I.F. (2007). Change in higher education: Understanding and responding to individual and organizational resistance. J Vet Med Educ 34(2):85-92

Lanteigne, G., and Bouchard, C. (2016) Is the introduction of an accreditation program likely to generate organization-wide quality, change and learning? Int J Health PlannMgmt, 31: e175-e191. doi: 10.1002/hpm.2314.

Lichy, J., \&Pon, K. (2015). For better or for worse: the changing life of academic staff in French business schools. Journal of Management Development, 34(5), 536-552.

Lightbody, M. (2010). Exacerbating staff shortages and student dissatisfaction? The impact of AACSB accreditation on faculty recruitment in Australia, Australasian Accounting Business and Finance Journal, 4(2), 3-18.

Lowrie, A., \& Willmott, H. (2009). Accreditation sickness in the consumption of business education: The vacuum in AACSB standard setting. Management Learning, 40(4), 411-420.

Ministry of Education Malaysia 2012, Malaysia Education Blueprint 2013-2025, Ministry of Education, Malaysia, viewed 30 December 2014 < http://www.moe.gov.my/userfiles/file/PPP/PreliminaryBlueprint-Eng.pdf>

Ministry of Higher Education Malaysia (2012), The National Graduate Employability Blueprint 20122017, $\quad$ viewed 1 July 2015, <http:http://www.mohe.gov.my/portal/images/utama/penerbitan/TNGEblueprint/GE\%20blueprin t\%202012-2017.pdf>. (2015), Malaysia Education Blueprint (Higher Educatioan) 2015-2025, viewed 24 May 2016,

<http://www.mohe.gov.my>

Morgan, J. (2011). The Impact of AACSB Business School Accreditation on Quality of Accounting Education as Measured by CPA Exam Success Rates.Business Education Digest, (18).

Roberts, W. A., Johnson, R., \& Groesbeck, J. (2004).The faculty perspective on the impact of AACSB accreditation.Academy of Educational Leadership Journal, 8(1), 111-125.

Rollins, R.K, Lynch, D.C, Owen J,A, Shipengrover J,A., Peel, M.E, and Chakravarthi, S. (1999). Moving from policy to practice in curriculum change at the University of Virginia School of 
Medicine, East Carolina University School of Medicine, and SUNY-Buffalo School of Medicine.Acad Med 74(1 Suppl):S104-S111.

Romero, E. J. (2008). AACSB accreditation: Addressing faculty concerns. Academy of Management Learning \& Education, 7(2), 245-255

Sefton A,J. (2004). New approaches to medical education: An international perspective. Med PrincPract 13(5):239-248

Sharma, Y. (2015). Universities bear the brunt of cuts as economy slows. University World News. $\begin{array}{llll}\text { Retrieved July } 27, & 2016, & \text { from }\end{array}$ www.universityworldnews.com/article.php?story=20151029210957170

Szanton, P 1981, Not well advised, Russell Sage Foundation and the Ford Foundation, New York. vanDelden, P. (1992), Professionals: Quality of the Profession, Contact, Amsterdam

Van Kemenade, E., \&Hardjono, T. W. (2009). Professionals freaking out: the case of accreditation in Dutch higher education. The TQM Journal, 21 (5), 473 - 485.

Wheelen,\& Hunger. (2012). Strategic Management \& Business Policy (13 ed.): Pearson, New Jersey White, J. Paslawski T. and Kearney, R. (2013) 'Discovery Learning': An account of rapid curriculum change in response to accreditation, Medical Teacher, 35:7, e1319-e1326, DOI:

10.3109/0142159X.2013.770133 